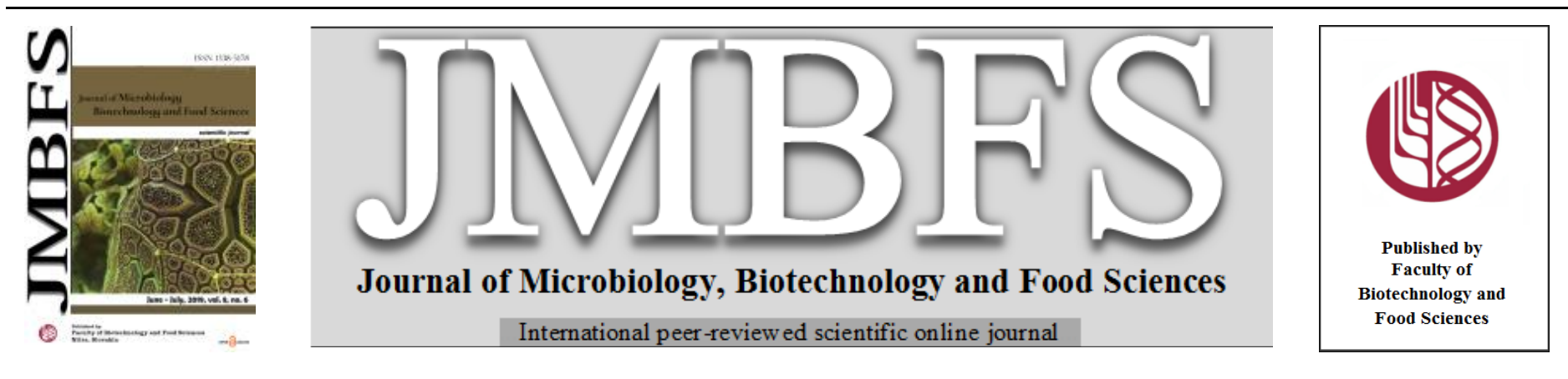

\title{
THE QUALITY OF HONEYS INFLUENCED BY THE TRADITIONAL HEATING METHOD
}

\author{
Lynda Haouam ${ }^{1, *}$, Hélène Dailly ${ }^{2}$,Etienne Bruneau ${ }^{2}$ and Ali Tahar ${ }^{3}$
}

\author{
Address(es): \\ ${ }^{1}$ Department of Biology, Faculty of Natural and Life Sciences, University of Souk Ahras, Souk-Ahras 41000, Algeria. \\ ${ }^{2}$ Beekeeping Centre of Research and Information (CARI), Place Cross South 4bte L7.07.09, 1348 Louvain-La Neuve, Belgium. \\ ${ }^{3}$ Laboratory of Plant Biology and Environment, Department of Biology, Faculty of Sciences, University Badji Mokhtar-Annaba, Annaba 23000, Algeria.
}

*Corresponding author: 1.haouam@univ-soukahras.dz

doi: 10.15414/jmbfs.2019.8.6.1276-1280

\section{ARTICLE INFO}

Received 19.9. 2018

Revised 15. 1. 2019

Accepted 29. 1. 2019

Published 1. 6. 2019

Regular article

open $\partial_{\text {ACCESS }}$

\begin{abstract}
In this study, three parameters (hydroxymethylfurfural, diastase activity and invertase activity) were used to evaluate the quality of twenty samples of multifloral honey from northern Algeria heated by a traditional method (conventional heating in a water bath at 100 $\left.{ }^{\circ} \mathrm{C}\right)$ for five treatment periods $(2,4,6,8$ and $16 \mathrm{~min})$. The assay was carried out with honey samples whose initial HMF, diastase activity and invertase activity values were within the recommended food authority limit. HMF was determined by HPLC, diastase was measured with Phadebas and invertase was determined using the Siegenthler method. During heating, it was observed an increase in the HMF related to an increase in temperature, but still below the international standard limit $\left(40 \mathrm{mg} \cdot \mathrm{kg}^{-1}\right)$. Diastase activity and invertase activity also decreases during heating. However, invertase is more heat-sensitive and heating time than diastase and HMF, and it's an important parameter to determine if honey has been submitted to heating. Therefore to liquefy honey we can use this method but with a low temperature and a short time because time has a deep impact on the quality of heating treatment of honey.
\end{abstract}

\section{INTRODUCTION}

Honey is a product that contains a blend of complex carbohydrates, mostly monosaccharides glucose and fructose. Others are present in lower amounts, according to the botanical origin. Moreover, other compounds such as organic acids, lactones, amino acids, mineral salts, vitamins, enzymes, pollen, wax and pigments are present (Fallico et al., 2004)

The enzymes are secreted by bees (invertase, glucose oxidase and amylase) or by plants (amylase, catalase and phosphatase) (Vorlova and Čelechovská, 2002) Honey contains small amounts of different enzymes, the most important of which are diastase $(\propto$-amylase), invertase $(\propto$-glucosydase), glucose oxidase, catalase and acid phosphatase (White, 1975). They are sensitive to heat and therefore are able to indicate overheating of the product and the degree of conservation (Ahmed et al., 2013). The activity of enzyme in honey also depends on age of the bees, stage of the colony, nectar flow, environmental conditions and the beekeeping practices (Karabournioti and Zervalaki, 2001).

According to several authors the activity of invertase in honey is used mainly in Europe for the evaluation of monofloral honeys, as well as for the determination of the characteristics related to the geographical origin of the different types of honey (Oddo et al., 1999; 2004; Bartakova et al., 2007; Serrano et al., 2007). Honey freshness is generally evaluated by determining the value of parameters that increase or decrease with overheating and/or ageing. The most commonly used are hydroxymethylfurfurale, diastase and invertase (Oddo et al., 1999) However, excessive heat treatment leads to the formation of 5hydroxymethylfurfuraldehyde (Nozal et al., 2001). Hydroxymethylfurfural (HMF) is a cyclic aldehyde produced as a result of sugar degradation (Cervantes et al., 2000). HMF value is virtually absent or very low in fresh honey and is high in honey that has been heated, stored in non-adequate conditions and old honey (Nozal et al., 2001; Khalil et al., 2010). At room temperature, the action of normal honey acidity on reducing sugars can possibly produce HMF. It has a toxic effect and also induces reactive oxygen species (De Smet et al., 2015).

The Alimentarius Codex (2001) and International Honey Commission (Bogdanov et al., 1997), set the maximum concentration of HMF to $40 \mathrm{mg} . \mathrm{kg}$ ${ }^{1}$ for honey from non-tropical regions and high values of HMF $\left(80 \mathrm{mg} \cdot \mathrm{kg}^{-1}\right)$ from countries or regions with tropical ambient temperatures. Extremely high values of HMF (>500 mg.kg ${ }^{-1}$ ) demonstrate adulteration with invert syrup (Coco et al., 1996).
Usually the heating process is used to reduce viscosity, and to prevent crystallization or fermentation (Singh et al., 1988). According to Bakier (2006), the effective liquification of honey requires heating for at least $10 \mathrm{~min}$ at $52-55$ ${ }^{\circ} \mathrm{C}$. Honey heating is carried out in two different ways: in air-ventilated chambers, at $45-50{ }^{\circ} \mathrm{C}$ for $4-7$ days or by immersion of honey drums in hot water. Although, the second heating method is more efficient, the first is the most common (Belitz and Grosch, 1999). Algeria is a broad territory extends over an area of 2,381,741 km2 and is the second largest country in Africa (Haouam et al., 2016), in this country immersion of honey bottle in hot water for liquefaction is more used.

In this context, the aim of this study is to test the quality of honey and the efficiency of the traditional method of heating by analyzing the HMF content, the diastase activity and invertase activity in twenty honey samples from north of Algeria, treated by the traditional heating method (immersion the bottle of honey in hot water) and compare their levels by while five treatment periods.

\section{MATERIAL AND METHODS}

\section{Honey samples}

Twenty multifloral honey samples of Apis mellifera intermissa were produced in various regions from north of Algeria (Table 1) and (Figure 1) and were collected from beekeepers. All samples were collected in airtight plastic containers while the same year and then they have been stored in a refrigerator at $4-5{ }^{\circ} \mathrm{C}$ until analysis.

\section{Heating procedure}

Each honey sample was divided into six sub-samples of about $5 \mathrm{~g}$ in glass bottles. One portion was immediately analyzed and five portions in closed bottles were undergo a thermal processing (conventional heating in a water bath- isothermal heating) without stirring, during five periods of treatment (2, 4, 6, 8 and 16 min). The conventional heating procedure was as follows: $2,4,6$ and 16 min at $100^{\circ} \mathrm{C}$ and cooled down in a room temperature. The temperature of the analysis was selected on the basis of the traditional heating (dilution the bottle of honey in the saucepan with water boiling). Heat-treated samples were subjected to Hydroxymethylfurfural (HMF), diastase activity and invertase activity analyses. 
Table 1 Botanical and geographical origin of honey samples

\begin{tabular}{|c|c|c|c|}
\hline Samples & Honey type & Geographical origin & Region \\
\hline $\mathrm{H} 1$ & \multirow{20}{*}{ Multifloral } & M'Sila & Bossada \\
\hline $\mathrm{H} 2$ & & Djelfa & Ain Wessera \\
\hline H3 & & Lagoute & Aflou \\
\hline $\mathrm{H} 4$ & & Mila & Mila \\
\hline H5 & & Khenchla & Chachare \\
\hline H6 & & Oum- El- Bouaghi & Meskianna \\
\hline $\mathrm{H} 7$ & & \multirow{4}{*}{ Tebessa } & Oinza \\
\hline $\mathrm{H} 8$ & & & Ain Zargua \\
\hline H9 & & & Yokous \\
\hline H10 & & & $\begin{array}{ll}\text { Limit } & \text { Tebessa- } \\
\text { Tunisie } & \end{array}$ \\
\hline H11 & & Guelma & Bouati mahmoud \\
\hline H12 & & Skikda & El Marsa \\
\hline H13 & & \multirow{5}{*}{ Annaba } & Edough Seraidi \\
\hline H14 & & & Oued El Aineb \\
\hline H15 & & & Berhel \\
\hline H16 & & & Triaate -Berahel \\
\hline H17 & & & Bomaiza \\
\hline H18 & & \multirow{3}{*}{ El-Taref } & El-Taref \\
\hline H19 & & & West Ben Mhidi \\
\hline $\mathrm{H} 20$ & & & $\begin{array}{l}\text { Bounamousa- Ben } \\
\text { Mhidi }\end{array}$ \\
\hline
\end{tabular}

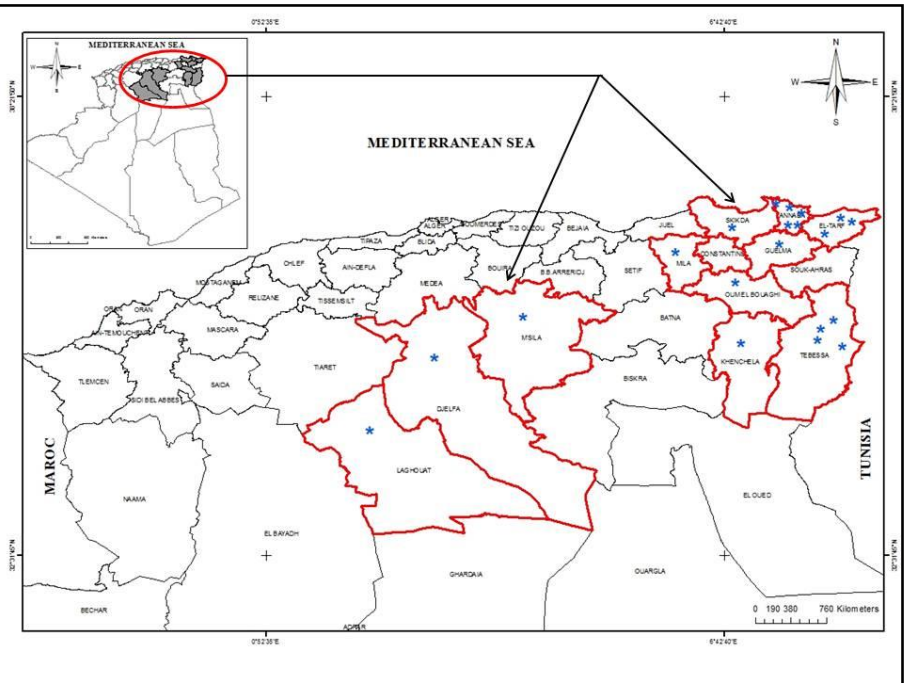

Figure 1 Distribution of honey samples from north of Algeria

\section{Hydroxymethylfurfural analysis}

HMF (5-(hydroxymetyl-) furan-2-carbaldehyde) was determined by reverse phase HPLC Agilent 1200 (Ramsey, Minnesota, USA) equipped with UV detector, according to the harmonized by the European Honey Commission (Bogdanov et al., 1997). Five gram of honey sample was weighed into a $50 \mathrm{~mL}$ beaker and dissolved in $25 \mathrm{~mL}$ HPLC grade water. The solution was transferred into $50 \mathrm{~mL}$ volumetric flask and filled to the mark with HPLC grade water. Then the solution was centrifuged and poured into sample vials for chromatographic separation. The HPLC condition was the following: mobile phase, $90 \%$ water and $10 \%$ acetonitrile; flow rate $1 \mathrm{ml} / \mathrm{min}$; injection volume $20 \mu \mathrm{l}$. HMF content of the sample was calculated by comparing the corresponding peak areas of the sample and those of the standard solutions, taking into account the dilution factor Results were expressed in $\mathrm{mg} \cdot \mathrm{kg}^{-1}$.

\section{Enzyme analysis}

\section{Diastase activity analysis}

Diastase activity was measured by Phadebas, according to the harmonized Methods of the European Commission of Honey (Bodganov et al., 1997; Tosi $\boldsymbol{e}$ al., 2008), using spectrophotometric method. Diastase activity is the one unit corresponds to the enzyme activity of $1 \mathrm{~g}$ honey that can hydrolyse $0,01 \mathrm{~g}$ of starch in $1 \mathrm{~h}$ at $40^{\circ} \mathrm{C}$ (Oddo et al., 1999). According to Oddo and Pulcini (1999) the number of diastases (ND) is calculated with the following equation: $\mathrm{ND}=-4.37 \times\left(\Delta \mathrm{A}_{620}\right)^{2}+3.38 \times\left(\Delta \mathrm{A}_{620}\right)+0.03$ and the results were expressed in Schade units.

\section{Invertase activity analysis}

Invertase was determined using the Siegenthler method, according to the harmonized by the European Honey Commission (Bogdanov et al., 1997). The enzyme activity is evaluated photometrically, by measuring the decomposition of the substrate p-nitrophenyl $\alpha$-D glucopyranoside into the product p-nitrophenol (which has a maximum absorbance at $400 \mathrm{~nm}$ ). The results were expressed as invertase number (IN). The IN indicates the amount of sucrose per gram hydrolysed in $1 \mathrm{~h}$ by the enzymes contained in $100 \mathrm{~g}$ of honey under test conditions (Oddo et al., 1999).

\section{Statistical analysis}

A one-way analysis of variance (ANOVA) was performed to examine the effects of heating at five period of treatment on HMF, diastase activity and Invertase activity with their initial values. F-test was used to estimate the statistically significant differences (P-value <0.05) among honey samples. The differences among the means were determined for significance at the 5\% level using Tukey's test. All the analyses were carried out at least in duplicate, and the results are expressed as mean values \pm standard deviations (SDs). All data were analyzed using the Statistica 8.0 software for windows from Statsoft.

\section{RESULTS AND DISCUSSION}

The variation of HMF contents, diastase activity and invertase activity according to initial value and different period of treatment of honey are reported in Table 2. As well as the number of samples exceeding limit presented in Table 3.

Table 2 Variation of HMF, diastase activity and invertase activity during the period of treatment $(n=20)$

\begin{tabular}{|c|c|c|c|c|c|c|c|c|c|}
\hline \multirow{2}{*}{ Time } & \multicolumn{3}{|c|}{$\operatorname{HMF}\left(\mathrm{mg} \cdot \mathrm{kg}^{-1}\right)$} & \multicolumn{3}{|c|}{ Diastase activity (Schade units ) } & \multicolumn{3}{|c|}{ Invertase activity (IN) } \\
\hline & $p$-value & rang & mean \pm sd & $p$-value & range & mean $\pm \mathrm{sd}$ & $p$-value & range & mean $\pm \mathrm{sd}$ \\
\hline $0 \mathrm{~min}$ & - & $0.69-09.50$ & $3.72 \pm 2.45^{\mathrm{a}}$ & - & $9.62-29.47$ & $19.37 \pm 5.35^{\mathrm{a}}$ & - & $38.01-163.91$ & $101.93 \pm 37.23^{\mathrm{a}}$ \\
\hline $2 \min$ & $\mathrm{ns}$ & $0.15-10.08$ & $4.69 \pm 3.22^{\mathrm{b}}$ & $\mathrm{ns}$ & $10.12-28.72$ & $18.95 \pm 5.01^{\mathrm{a}}$ & $* *$ & $11.79-162.39$ & $71.41 \pm 39.04^{\mathrm{b}}$ \\
\hline $4 \min$ & ns & $0.58-11.23$ & $4.18 \pm 3.31^{\mathrm{b}}$ & ns & $7.60-28.26$ & $15.96 \pm 4.74^{\mathrm{a}}$ & $* * *$ & $0-115.15$ & $23.54 \pm 36.12^{\mathrm{c}}$ \\
\hline $6 \mathrm{~min}$ & ns & $0.52-12.13$ & $4.82 \pm 3.46^{\mathrm{b}}$ & $* * *$ & $0.47-28.26$ & $9.12 \pm 8.17^{\mathrm{b}}$ & $* * *$ & $0-53.91$ & $1.10 \pm 18.63^{\mathrm{c}, \mathrm{d}}$ \\
\hline $8 \min$ & ns & $0.18-12.59$ & $4.60 \pm 3.69^{\mathrm{b}}$ & $* * *$ & $0.00-25.47$ & $5.62 \pm 7.50^{\mathrm{b}, \mathrm{c}}$ & $* * *$ & 0.0 & $0 \pm 0^{\mathrm{d}}$ \\
\hline $16 \mathrm{~min}$ & $* *$ & $0.55-23.85$ & $8.20 \pm 4.97^{\mathrm{b}}$ & $* * *$ & $0.11-15.45$ & $2.16 \pm 3.81^{\mathrm{c}}$ & $* * *$ & 0.0 & $0 \pm 0^{\mathrm{d}}$ \\
\hline
\end{tabular}

HMF - hydroxymethylfurfural, $\mathrm{n}-$ number of samples, $\mathrm{ns}$-not significant, sd - standard deviation, $* *$ significant at $\mathrm{p}<0.01, * * *$ significant at $\mathrm{p}<$ 0.001 , With different letters are significantly different 
Table 3 Variation of HMF, diastase activity and invertase activity during the period of treatment $(n=20)$

\begin{tabular}{|c|c|c|c|c|c|c|c|c|c|}
\hline \multirow[b]{2}{*}{ Time } & \multicolumn{3}{|l|}{$H M F\left(\mathrm{mg} \cdot \mathrm{kg}^{-1}\right)$} & \multicolumn{3}{|c|}{ Diastase activity (Schade units) } & \multicolumn{3}{|c|}{ Invertase activity (IN) } \\
\hline & $\begin{array}{l}\text { International } \\
\text { standard limit }\end{array}$ & $\begin{array}{l}\text { Samples } \\
\text { exceeding } \\
\text { limit }\end{array}$ & $\begin{array}{l}\text { Samples } \\
\text { conforming } \\
\text { limits }(\%) \\
\end{array}$ & $\begin{array}{l}\text { International } \\
\text { standard limit }\end{array}$ & $\begin{array}{l}\text { Samples } \\
\text { below limit }\end{array}$ & $\begin{array}{l}\mathrm{P} \text { Samples } \\
\text { conforming } \\
\text { limits (\%) }\end{array}$ & $\begin{array}{l}\text { International } \\
\text { standard limit }\end{array}$ & $\begin{array}{l}\text { Samples } \\
\text { below limit }\end{array}$ & $\begin{array}{l}\text { Samples } \\
\text { conforming } \\
\text { limits (\%) }\end{array}$ \\
\hline $0 \mathrm{~min}$ & \multirow{6}{*}{$\max .40$} & 0 & 100 & \multirow{6}{*}{$\max .8$} & 0 & 100 & \multirow{6}{*}{$\max .10$} & 0 & 100 \\
\hline $2 \min$ & & 0 & 100 & & 0 & 100 & & 0 & 100 \\
\hline $4 \min$ & & 0 & 100 & & 1 & 95 & & 12 & 40 \\
\hline $6 \mathrm{~min}$ & & 0 & 100 & & 11 & 45 & & 14 & 30 \\
\hline 8 min & & 0 & 100 & & 13 & 35 & & 20 & 0 \\
\hline $16 \mathrm{~min}$ & & 0 & 100 & & 18 & 10 & & 20 & 0 \\
\hline
\end{tabular}

\section{Hydroxymethylfurfural (HMF)}

\section{HMF content in untreated honey}

Hydroxymethylfurfural (HMF) is absent or present in trace amounts in fresh honeys, since it is a parameter of honey freshness (Sodre et al., 2011). HMF level in fresh honey samples (at time $0 \mathrm{~min}$ ) varied between 0.69 and $9.50 \mathrm{mg} . \mathrm{kg}$ ${ }^{1}$, these results were indicated HMF contents were below $10 \mathrm{mg} \cdot \mathrm{kg}^{-1}$, similar results were observed by Getu and Birhan (2014) for Ethiopian honey (HMF ranged between 0.5 and $3.2 \mathrm{mg} \cdot \mathrm{kg}^{-1}$ ). According to Al-Farsi et al. (2018) high quality honey should present low HMF contents. All fresh honey samples studied contained HMF within the recommended food authority limit $\left(40 \mathrm{mg} \cdot \mathrm{kg}^{-1}\right)$ According to White (1994) proposed the HMF level as the only reliable heating/storage index in honey.

\section{Effect of heating on HMF contents}

HMF, this product of fructose decomposition, increases with storage and prolonged heating of honey (Al-Farsi et al., 2018). During heating from initial value $(0 \mathrm{~min})$ to $8 \mathrm{~min}$ all honey samples showed not formation of HMF their values maximum varied from 9.50 to $12.59 \mathrm{mg} \cdot \mathrm{kg}^{-1}$ (Figure 2). These results are in agreement with those of Fallico et al. (2004), at high temperature $\left(100^{\circ} \mathrm{C}\right)$ no difference, related to HMF formation, can be measured among honeys of different origin. At time $16 \mathrm{~min}$ all samples had a slight increase to the maximum $23.85 \mathrm{mg} \cdot \mathrm{kg}^{-1}$. In this time there is a remarkable HMF formation, moreover a significant difference $(p<0.001)$ was also observed between honeys, but still below the international standard limit $\left(40 \mathrm{mg} \cdot \mathrm{kg}^{-1}\right)$. The same authors Fallico et al. (2004) showed that the HMF levels in honey samples, heated at $100{ }^{\circ} \mathrm{C}$, were significant correlated only with time of heating. Singh and Bath (1997) reported that with increasing heating time of $0-30 \mathrm{~min}$, an increased in intensity of HMF formation for three monofloral honeys from India at $65^{\circ} \mathrm{C}$.

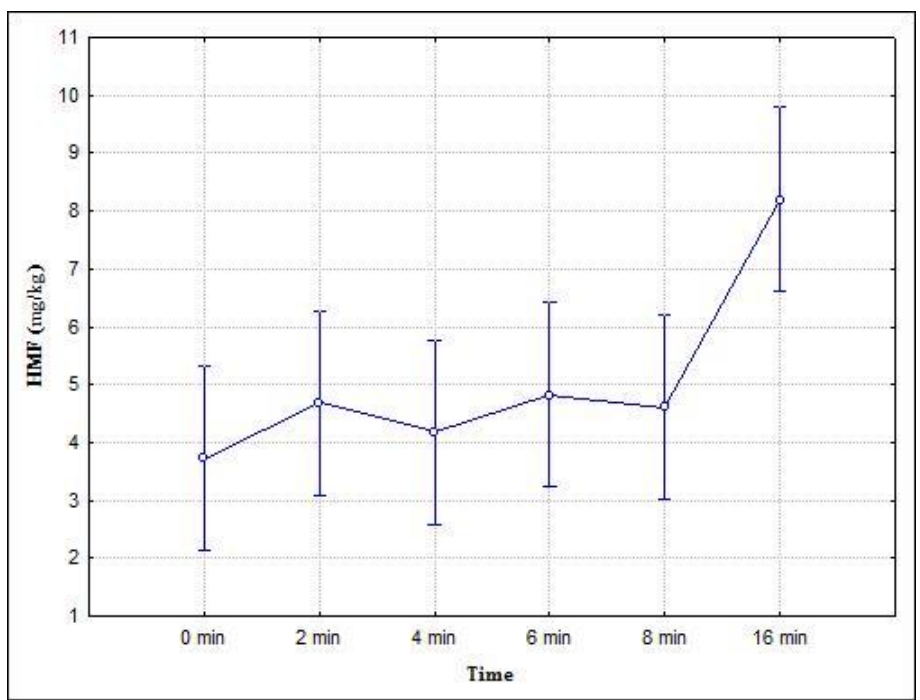

Figure 2 Variation of HMF during heating

\section{Enzymes}

Diastase activity in untreated honey

The diastase activity is a very interesting enzyme to know the freshness of honey (Oddo et al., 1990). The diastase content in our samples ranged between 9.62 and 29.47 Schade units. Similar values for diastase reported in Argentina honey which averaged 19.7 Schade units. (Cantarelli et al., 2008). According to the European Codex Honey Standards, a well-processed and ready to be consumed honey must contain diastase number ID $\geq 8$ Schade units. We noted that $100 \%$ of fresh honey samples studied contained ID $\geq 8$ Schade units. The enzyme activity in honey from the same floral origin can possibly vary, due to the plant's nectar secretion quality and quantity, which was influenced by the contribution of the environment and the presence of different geographical races of bees, which is mainly governed by biotic and abiotic factors (Adgaba et al., 2017; Belay et al., 2017).

\section{Effect of heating on diastase activity}

During heating from initial value $(0 \mathrm{~min})$ to time $4 \mathrm{~min}$ (Figure 3$)$, the diastase activity of all honey samples showed some differences were seen. The mean values decrease from $19.37 \pm 5.35$ Schade units to $15.96 \pm 4.74$ Schade units, but is not significant because only one sample reports a value below the limit. At time 6 min all samples had a slight decrease to $9.12 \pm 8.17$ Schade units, in addition a very highly significant difference $(p<0.001)$ was observed, therefore 11 samples of multiflora were unconfirmed to the European Codex Honey Standards limit (diastase number "ID" $\geq 8$ Schade units). According to Bogdanov et al. (1999) and White (1994) the honeys are also used as a quality parameter even though some have a lower level of enzymes intrinsically. Honeys with lower level of enzyme, needs to consist essentially a maximum of $15 \mathrm{mg} . \mathrm{kg}$ ${ }^{1}$ of HMF Zappala et al. (2005). At time 8 and 16 min the mean values of the diastase activity was also decrease from $5.62 \pm 7.50$ Schade units to $2.16 \pm 3.81$ Schade units respectively therefore lower of 8 Schade units. In addition a very highly significant difference $(\mathrm{p}<0.001)$ was also been noticed in these times $(8$ and $16 \mathrm{~min}$ ), therefore 13 samples and 18 samples of multifloral respectively were below to limit, with the exception of two samples that have values above the limits at $16 \mathrm{~min}$.

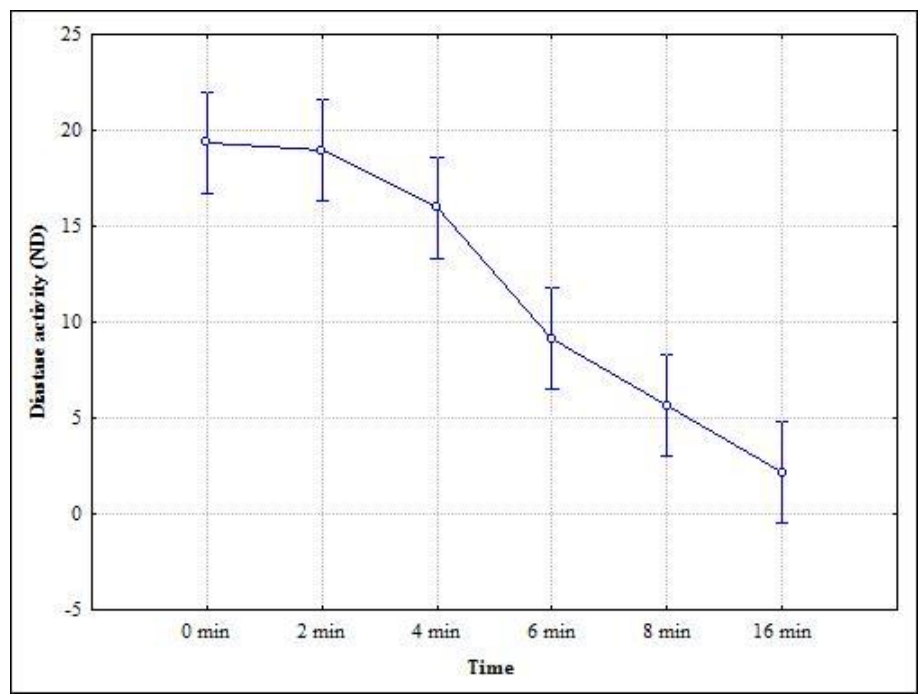

Figure 3 Variation of diastase activity during heating

\section{Invertase activity in untreated honey}

In particular, invertase is the enzyme responsible for converting sucrose, maltose, mélézitose, raffinose, cellobiose and tréhalose to fructose and glucose which are the main sugars in honey (White, 1975; Parvanov, 2012). The mean value of invertase activity in fresh honey simples is $101.93 \pm 37.23 \mathrm{IN}$ with a minimum value observed is $38.01 \mathrm{IN}$. The invertase activity is variable in the different types of honey, the minimum values of its activity have been proposed by the 
International Honey Commission (IHC): $\geq 50 \mathrm{IN}$ for normal honeys, $\geq 20 \mathrm{IN}$ for honeys with a low enzymatic activity and $\geq 10 \mathrm{IN}$ for monofloral honeys (from Arbutus sp., Robinia sp. and Erica sp. (Bogdanov et al., 1997). Therefore we noted that $100 \%$ of fresh honey samples studied contained the value of invertase activity $\mathrm{IN} \geq 20 \mathrm{IN}$.

\section{Effect of heating on invertase activity}

During heating the invertase activity of all honey samples showed some differences were seen (Figure 4), the mean values decrease from $101.93 \pm 37.23$ $\mathrm{IN}$ to $71.41 \pm 39.04 \mathrm{IN}$ at time $2 \mathrm{~min}$ and to $23.54 \pm 36.12 \mathrm{IN}$ at time $4 \mathrm{~min}$, according to Karabournioti and Zervalaki (2001), the decrease of invertase is very fast and starts from the temperature of $35^{\circ} \mathrm{C}$, is the temperature that in many countries can be obtained during the summer. In addition the results of one-way analysis of variance (ANOVA) showed a highly significant difference $(\mathrm{p}<0.01)$ at $2 \mathrm{~min}$ and a very highly significant difference $(\mathrm{p}<0.001)$ at $4 \mathrm{~min}$, but still above the International Honey Commission limit (invertase activity $\geq 10 \mathrm{IN}$ ). At time 6 to 16 min a very highly significant difference $(\mathrm{p}<0.001)$ was also observed and the mean values of the invertase activity are respectively $1.10 \pm 18.63 \mathrm{IN}, 0 \pm 0$ IN and $0 \pm 0 \mathrm{IN}$ however lower of $10 \mathrm{IN}$. Therefore the number of samples below limit was respectively decreased from 14 samples to 20 samples. These results showed that the values of the invertase activity are inversely proportional to the heating period. Invertase is considered the best indicator of freshness that diastase because it is more sensitive to heat (Oddo et al., 1999). According to the European Honey Commission the invertase activity could serve as a criterion for determining whether honey is stored long-term or heated at high temperatures (Bogdanov et al., 1997).

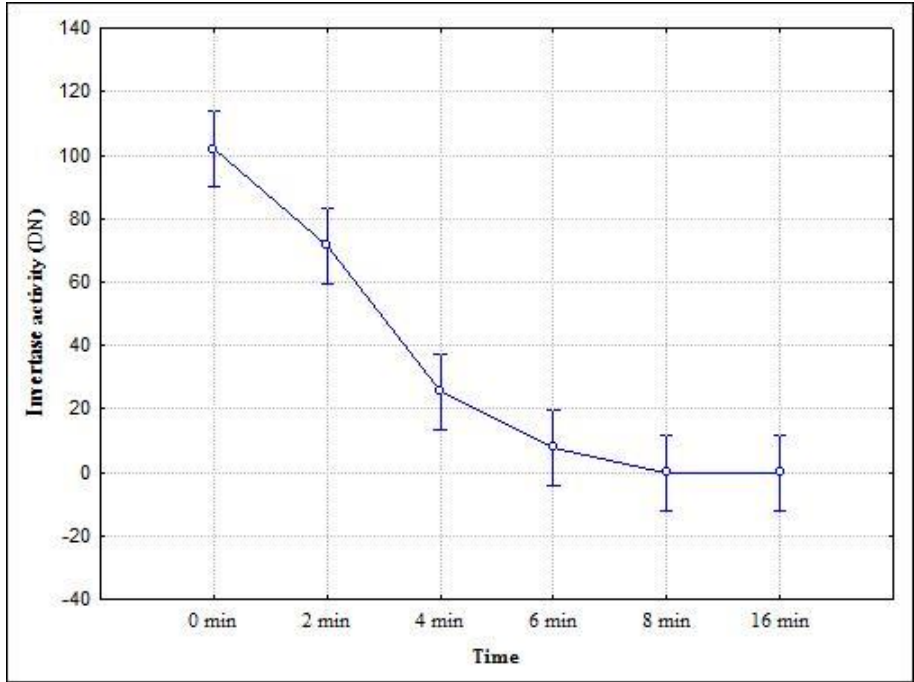

Figure 4 Variation of invertase activity during heating

\section{CONCLUSION}

We concluded that hydroxymethylfurfural (HMF), diastase activity and invertase activity concentrations in fresh multifloral honey samples from north of Algeria were within the internationally recommended range. The traditional heating (Conventional heating in the water bath at $100{ }^{\circ} \mathrm{C}$ ) effect on the three parameters studied during five periods of treatment $(0,2,4,6,8$ and $16 \mathrm{~min})$ were found to be significantly different in HMF at $16 \mathrm{~min}$, diastase activity at $6 \mathrm{~min}$ and invertase activity at $4 \mathrm{~min}$, but still within the international standard limit. The results show that invertase is more heat-sensitive and heating time than diastase and HMF. It is obvious that heating is not the only factor influencing HMF formation in honey and the destruction of enzymes, but the most important is the heating time.

Acknowledgments: This work was funded by grants from the "Direction Générale de la Recherche Scientifi que et du Développement Technologique" (DGRSDT). Thanks are given to all the beekeepers that have generously provided the honey samples to carry out this study.

\section{REFERENCES}

ADGABA, N., AL-GHAMDI, A., TADESSE, Y., GETACHEW, A., AWAD, A.M., ANSARI, M.J., ALQARNI, A.S. 2017. Nectar secretion dynamics and honey production potentials of some major honey plants in Saudi Arabia. Saudi Journal of Biological Sciences, 24,180-191. https://doi.org/10.1016/j.sjbs.2016.05.002

AHMED, M., DJEBLI, N., AISSAT, S., KHIATI, B., MESLEM, A., BACHA S. 2013. In vitro activity of natural honey alone and in combination with curcuma starch against Rhodotorula mucilaginosa in correlation with bioactive compounds and diastase activity. Asian Pacific Journal of Tropical Biomedicine, 3(10), 816821. https://doi.org/10.1016/S2221-1691(13)60161-6

AL-FARSI, M., AL-BELUSHI, S., AL-AMRI, A., AL-HADHRAMI, A., ALRUSHEIDI, M., AL-ALAWI, A. 2018. Quality evaluation of Omani honey. Food chemistry, 262, 162-167. https://doi.org/10.1016/j.foodchem.2018.04.104

ALIMENTARIUS, C. 2001. Revised codex standard for honey. Codex stan, 12 1982.

Bakier, S. 2006. Odwracalność procesu krystalizacji miodu. Postępy Techniki Przetwórstwa Spożywczego, 16, 30-34.

BELAY, A., HAKI, G. D., BIRRINGER, M., BORCK, H., LEE, Y. C., KIM, K. T., BAYE, K., MELAKU, S. 2017. Enzyme activity, amino acid profiles and hydroxymethylfurfural content in Ethiopian monofloral honey. Journal of Food Science and Technology, 54(9), 2769-2778. https://doi.org/10.1007/s13197-0172713-6

BELITZ, H. D., GROSCH, W. 1999. Food chemistry. Berlin, New York: Springer-Verlag.

BOGDANOV, S., MARTINN, P., LÜLLMANN, C. 1997. Harmonised Methods of the European Honey Commission. Apidologie, Extra Issue, 1-59.

BOGDANOV, S., LULLMAN, C., MARTIN, P., VON DER OHE, W., RUSSMANN, H., VORWOHL, G., PERSANO-ODDO, L., SABATINI, A. G., MARCAZZAN, G. L., PIRO, R., FLAMINI, C., MORLOT, M., HERITIER, J., BORNECK, R., MARIOLEAS, P., TSIGOURI, A., KERKVLIET, J., ORTIZ, A., IVANOV, T., D’ARCY, B., MOSSEL, B., VIT, P. 1999. Honey quality and international regulatory standards: review by the international honey commission. Bee World, 80(2), 61-69. https://doi.org/10.1080/0005772X.1999.11099428

BARTAKOVA, K., VORLOVA, L. TITERA, D., LUTZOVA, M. 2007. Physicochemical parameters and botanical origin of Czech honeys. Journal of Food and Nutrition Research, 46, 167-173.

CANTARELLI, M. A., PELLERANO, R. G., MARCHEVSKY, E. J., CAMINA, J. M. 2008. Quality of honey from Argentina: Study of chemical composition and trace elements. Journal of the Argentine Chemical Society, 96(1-2), 33-41.

CERVANTES, M.A. R., NOVELO, S. G., DUCH, E. S. 2000. Effect of the temporary thermic treatment of honey on variation of the quality of the same during storage. Apiacta, 35, 4.

COCO, F. L., VALENTINI, C., NOVELlI, V., CECCON, L. 1996. Highperformance liquid chromatographic determination of 2-furaldehyde and 5hydroxymethyl-2-furaldehyde in honey. Journal of Chromatography A, 749(1-2), 95-102. https://doi.org/10.1016/0021-9673(96)00392-5

DE SMET, L., SAEGERMAN, C., RAVOET, J., DE GRAAF, D. C. 2015 Hydroxylmethylfurfural induces reactive oxygen species (ROS)-dependent activation of the Toll pathway in honey bees. Julius-Kühn-Archiv, 450, 296

FALLICO, B., ZAPPALA, M., ARENA, E., VERZERA, A. 2004. Effects of conditioning on HMF content in unifloral honeys. Food chemistry, 85(2), 305313. http://dx.doi.org/10.1016/i.foodchem.2003.07.010

GETU, A., BIRHAN, M. 2014. Chemical analysis of honey and major honey productionchallenges in and around Gondar, Ethiopia. Academic Journal of Nutrition, 3(1), 06-14. https://doi.org/10.5829/idosi.ajn.2014.3.1.84322 HAOUAM, L., TAHAR, A. DAILLY, H., LAHRICHI, A., CHAQROUNE, A., ABDENNOUR C. 2016. Physicochemical properties and major elements contents of Algerian honeys from semi-arid regions. Emirates Journal of Food and Agriculture, 28(2), 107-115. http://dx.doi.org/10.9755/ejfa.2015-04-064

KARABOURNIOTI, S., ZERVALAKI, P. 2001. The effect of heating on honey HMF and invertase. Apiacta, 36(4), 177-181

KHALIL, M. I. SULAIMAN, S. A., GAN, S. H. 2010. High 5hydroxymethylfurfural concentrations are found in Malaysian honey samples stored for more than one year. Food and Chemical Toxicology, 48(8), 23882392. https://doi.org/10.1016/j.fct.2010.05.076

NOZAL, M. J., BERNAL, J. L., TORIBIO, L., JIMÉNEZ, J. J., MARTÍN, M. T. 2001. High-performance liquid chromatographic determination of methyl anthranilate, hydroxymethylfurfural and related compounds in honey. Journal of Chromatography A, 917(1), 95-103

ODDO, L. P., PIAZZA, M. G., PULCINI, P. 1999. Invertase activity in honey. Apidologie, 30(1), 57-65

ODDO, L. P., PULCINI, P. 1999. A scientific note on the Phadebas method for honeys with low enzyme content. Apidologie, 30(4), 347-348.

ODDO, L. P., PIANA, L., BOGDANOV, S., BENTABOL, A., GOTSIOU, P. KERKVLIET, J., MARTIN, P. MORLOT, M. VALBUENA, A. O. RUOFF, K., VON DER OHE, K. (2004). Botanical species giving unifloral honey in $\begin{array}{llll}\text { Europe. Apidologie, } & 35 & \text { (Supplement } & 1 \text { ), }\end{array}$ https://doi.org/10.1051/apido:2004045

PARVANOV, P., DINKOV, D., TANANAKI, C. 2012. Invertase activity and carbohydrate spectrum of organic acacia and polyfloral honey after one-year storage. Bulgarian Journal of Veterinary Medicine, 15(3), 198-205.

SERRANO, S., ESPEJO, R., VILLAREJO, M., JODRAL, M. L. 2007. Diastase and invertase activities in Andalusian honeys. International Journal of Food Science and Technology, 42(1), 76-79. https://doi.org/10.1111/j.1365 2621.2006.01213.x

SINGH, N., SINGH, S., BAWA, A. S., SEKHON, K. S. 1988. Honey-its food uses. Indian Food Packer, 42(6), 15-25. 
SINGH, N., BATH, P. K. 1997. Quality evaluation of different types of Indian honey. Food Chemistry, 58(1-2), 129-133. https://doi.org/10.1016/S03088146(96)00231-2

SODRE, G.S., MARCHINI, L.C., MORETI, A.C.C.C., OTSUK, I.P., CARVALHO, C.A.L. 2011. Physico-chemical characteristics of honey produced by Apis mellifera in the Picos region, state of Piaui, Brazil. Revista Brasileira de Zootecnia, 40, 1837-1843.

TOSI, E., CIAPPINI, M., RE, E., LUCERO, H. 2002. Honey thermal treatment effects on hydroxymethylfurfural content. Food chemistry, 77(1), 71-74. http://dx.doi.org/10.1016/j.foodchem.2007.04.025

VORLOVA, L., ČELECHOVSKÁ, O. 2002. Activity of enzymes and trace element content in the bee honey. Acta Vet. Brno, 71(3), 375-378.

WHITE, J. W. 1975. Physical characteristics of honey. Honey: A Comprehensive Survey. E. Crane, ed. ISBN 434902705.

WHITE, J. W. 1994. The role of HMF and diastase assays in honey quality evaluation. Bee world, 75(3), https://doi.org/10.1080/0005772X.1994.11099213

ZAPPALA, M., FALLICO, B., ARENA, E., VERZERA, A. 2005. Methods for the determination of HMF in honey: a comparison. Food control, 16(3), 273-277. http://dx.doi.org/10.1016/j.foodcont.2004.03.006 